Thirty-seven members of the College of Surgeons had sent up their names to be attached to the requisition about to be presented to Mr. Guthrie. The collegiate operation of the Council of that aggregate of pures has been an egregious blunder, which remains now to be rectified by the members--the general practitionerswhom the Council would willingly have the public to believe to be their inferiors. I rejoice, however, to think that there is now every prospect of the old adage, "Pride cometh before a fall," being verified in the case of the Council, and that the members are likely to regrain their own position in the College.

I am, Sir, your most obedient servant, P. Ballantine Fergusson.

Catharine place, Bath, July 8 th, 1845 .

"London, June 19th, 1845 .

"SIR,-I beg to acknowledge the receipt of your letter of yesterday, and to assure you, and the gentlemen for whom you act, that I shall have great pleasure in presenting their petition to the House of Commons, and that I shall to the utmost support its prayer. Every inquiry I have made convinces me that we are not ready for legislation, and that the delay of a session is absolutely necessary. Like yourselves, also, I object to multiplying unnecessarily the number of corporate bodies. To complicate machinery is always a bad thing, whether in politics or mechanics, and I should, in fact, prefer a one-college machine to that which needs two or three. It is clear, however, that neither the public nor the legislature are sufficiently informed in this matter. Time given for further inquiry cannot do harm, while precipitate and crude legislation may lead to lasting and enormous evil. I shall therefore strive earnestly for delay.

"I remain, Sir, your obedient servant,

« To Dr. P. B. Fergusson."

" J. A. RoEbuck.

\section{QUALIFICATIONS OF EXISTING PRACTITIONERS.} To the Editor of The Lancer.

SiR,-I cannot help expressing my regret at Dr. Pettigrew having, by the concluding remarks in his letter on this subject, published in your journal last week, detracted so much from his otherwise very excellent observations. I think that letter deserves special attention in the present crisis of our affairs; but in my humble opinion its conclusion should have been omitted, as it proves any. thing but what its author wishes. He has finished the building of his house with sand. By taking the London Medical Directory as his authority, although "it is the only work in which the names of men practising as medical attendants are collected together," he certainly has not fixed on infallibility; indeed, the editors themselves are fully aware of this, for in their preface they say, "it is scarcely possible that a work of this kind, containing such an immense number of facts, could be perfectly correct at its first appearance." One cannot help feeling surprised, then, that a gentleman so well acquainted with professional men as Dr. Pettigrew appears to be, should have endangered the force of his previous observations by taking as indisputable data that which the authors acknowledge may be faulty. To put down twentythree out of one hundred general practitioners as " having no right whatever, according to law, to practise in this department of the profession," surely required more consideration than a determination to "put them down," the red-book seeming to sanction it and how he could wish to lead "many unprofessional parties" to believe that half the general practitioners whose names he happened to find on one page of this book " possessed no qualification or even diploma," because it did not happen to be found there, $\mathbb{I}$ am at a loss to conjecture. It is evident many qualified gentlemen did not send in their qualifieations, though the work contains abundant proof that there were no lack of those who took especial pains to make their qualities known.

Trusting in your known desire to protect those who have been thonghtlessly condemned, and in your wish to see error righted, I doubt not your next journal will publish these remarks of, Sir, yours obediently,

A Legally-Qualified General Practitioner, whose qualification is not inserted in the Directory.

\section{CHOLESTERINE IN THE URINE.}

To the Editor of THE LANCET.

Sin, - I should not have noticed your anonymous correspondent's remarks upon my paper on Urine, but for the purpose of thanking him for giving me an opportunity of correcting an error respecting cholesterine. My opinion was expressed rather dubiously, because when I wrote it I was well aware the subject admitted of doubt. My words are, "Cholesterine is a substance very rich in carbon, supposed partly to give the colouring prin- ciple to the bile, and is of ten detected in the urine in the form of bile." If " I. M." will refer to Dr. Prout's work " On Stomach and Renal Diseases," 4th edition, page 507, he will there see the following opinion:- " These three substances, the resin of the bile, the cholesterine, and the colouring matter, seem in some degree to be allied to each other. Of the three ingredients, cholesterine is the only one which, as far as I know, has been examined. The colouring matter of hile is said to contain azote, which is not found either in the biliary resin or in the cholesterine."

In pages 511 and 562 of the same work, opinions rather different to the above are expressed. Dr. Golding Bird does not enter into the subject in his work on Urinary Deposits. Liebig and Turner say the colouring matter is separated from cholesterine by being dissolved in alcohol; and Prout says the colouring matter is insoluble in alcohol. If my paper had been on bile instead of urine, I should have been more careful. I still think that when bile is discovered in urine, the colouring matter, whatever it may be, is in combination with cholesterine.

All I know about the peculiar tint of the urine in chlorosis being connected with cystine is, that I have discovered in such urine the peculiar hexagonal prisms which Dr. Golding Bird so well delineates in page 116 of his work, and will gladly show them to "L. M." if an opportunity occurs. Cystine is well known to be present in scrofulous habits, and chlorosis is no unusual disease in such persons.

In conclusion, I would beg to ask "L. M." if he can tell me what the colouring matter of bile is?

I am, Sir, your obedient servant,

Rotherham, June 5th, 1845 Edward James Shearman.

\section{TIC DOULOUREUX.}

To the Editor of The Laxcet.

SrR,- It is not my intention to enter into a controversy with Mr. Gower, nor should I have deemed it requisite to notice his communication on tic douloureux, in The LanceT of the 28th ultimo, had he not misrepresented me, by affiliating sentiments in which I totally disbelieve, and charged me with discourteous demeanour towards Mr. Chippendale.

In the first place, I have never stated that tic douloureux is "idiopathic." We must not wiredraw technicalities too finely, but must receive them in their general aceeptation. Idiopathic is a term which, in contradistinetion to symptomatic, is commonly understood to mean a disorder which does not depend on another for its origin: in this sense I have invariably employed it, and have laboured, since my attention was first directed to the subject, to prove how extremely improbable a thing it is, that the morbid exaltation of function which occurs in the periphery of sentient nerves in neuralgic affections, can be produced without the agency of an efficient exciting cause.

$\mathrm{Mr}$. Gower asserts, that "odontalgia, arising from defective teeth, is a sympathetic affection." If we take this for granted, I fear we should be called upon to extend the bounds of this mysterious principle more widely than was ever contemplated even by the most sanguine sympathetic pathologist of bygone days.

With regard, in the next place, to the insinuation of uncourteous conduct, I have merely to say, that I leave the matter entirely in the hands of Mr. Chippendale; and I confidently appeal to that gentleman when $I$ ask, if, in the course of any allusions I have heretofore made to him, there be one expression which, by possibility, can be tortured into a personal offence? I am, Sir, your most obedient servant,

Parliament-street, Whitehall, July 4th, 1845 .

\section{R. H. Alinatrt.}

\section{ILLUSTRATION'S OF QUACKERY. To the Editor of The LANCET.}

Srn,-Surrounded by quackery and oppression as is our profession on every side, it is a difficult matter for that "unruly member," the tongue, or its vicegerent, the pen, to keep in a state of quietude. The medical practitioner is oppressed by those whom we should naturally think his guardians. In the first place, we have Lord Brougham with his Bill for non-imprisonment for debts under twenty pounds. The debts of general practitioners in the manufacturing districts are ninety-nine in a hundred beneath that sum, yet we are told by the partisans of this measure to trust to the honour of our patients. What is honour to a man who, by his own labour, has six children to support? A mere dissyllahic phantasm, which died with Don Quixote; yet, in another sense, a jewel, that would better become a toad's head or 
a swine's snout than either of our houses of parliament. Government patronage of quackery under the Stamp Act has been bad enough, but now Sir James Graham is about to open the floodgates of his liberality, and overwhelm us with the locusts of all countries. The only hope we have in Sir James is, his utter indecision; he seems to be a man who has neither possession of his own mind, nor that of anybody else. But so long as wise men visit Vanity Fair, and philosophers are found in the Paradise of Fools, no doubt his party will have hopes of Sir James.

Lord Byron, in some part of his inimitable Don Juan, says, "This is the patent age of new inventions For killing bodies and for saving souls."

So far as regards my own neighbourhood, the above lines are very true. First, we have the teetotallers, whose every doctrine is contained in the following distich:-

\section{"The grand preservative of life is water;}

All liquid, to mankind besides, is slaughter."

Next, we have the self-named hydropathists, who possess at Ilkley, a small village, six miles' distant, in the valley of the Wharfe, the largest institution of its kind in the kingdom. This is a mercantile or proprietary establishment, the grounds and building baving cost nearly one hundred thousand pounds. Its medical cuperintendence is invested in a soi-disant German M.D., who talks magpie-English to youthful hypochondriacs, widows on their preferment, and a host of lazy gluttons, who, to all appearance, are broken-winded from over-working their stomachs. This is really a beautiful place, the grounds are laid out with a taste perfectly tempting. The building is of the best stone, large and prepossessing, and capable of accommodating a great number of patients. Individuals who at home have been either too timid or idle to pursue a system of ablution, may here enjoy it with an ease worthy of Sardanapalus. There is nothing to do but to strip and back under a pipe or trap-door; there is no "Sesamé," but merely the touching of a string, and down rush gallons upon gallons of pure cold water, washing a way the accumulated filth of years; attendants are close at hand with towels to rub off the remaining sordes. When the reaction is perfect, the effects, after a few repetitions, are almost electrical.

The merchant from Leeds, or Bradford, not aware that he has had some thousands upon thousands of pores opened by which superfluities may be carried off, is perfectly agape in wonderment; he can eat a plain dinner; the process is renewed, his walks are extended; the whims and capriciousness of his appetite have disappeared; nothing comes wrong, all edibles are alike in fact, he can $\mathrm{swallow}$ milk and oatmeal porridge, and after a few weeks of ablution, plain living, and exercise, he returns to his home, less in weight but better in looks, and full of the wonders of cold water.

In order to make the thing more agreeable, a part of the building at Ilkley is appropriated to the purposes of a hotel, where grog, tobaceo, and cigars, are supplied to those who do not altogether believe that their bowels were made for aqueducts, or that pumps are proper acquaintances for men. . Occasionally you may see here parties of love-sick minors, of both sexes, ostensibly met for the purpose of dining or taking tea.

An individual who shall here be nameless, states by advertisement that he resides in Bloomsbury, and that he possesses an asinine appendage, or alphabetical tailpiece, beginning with D.D.; also that he is a clergyman, and can cure "nervous or mind complaints as certainly as water quenches thirst." I made some inquiries about his history, in vain. A few months afterwards, a neighbour put into my hands a book purporting to be the handicraft of this apostolic. I perused its contents. First came a canting exordium, wherein the author states that the practice of physic is in perfect unison with the sacerdotal character ; in proof of the assertion, and by way of palliating his own conduct, he cites, as instances, Christ and his apostles. This is all true. But a question to the man of cassock and bands :-Did not Christ and his apostles practise through a higher source than mere human knowledge? And by way of emolument, did they empty the pockets of the poor? The rest of the book I found a villanous assemblage of puffs. The whole volume was the joint property of a poor man, a paralytic, and a poor woman, a confirmed hypochondriac. The flattering advertisements had tempted them to its purchase, and its perusal had caused them to apply to the great Dr. Willis Moseley, who forthwith sent them a small wooden box, containing two green-glass quart bottles of what his patients characterized as sugar and water, with directions for use. The carriage of this amounted to eight shillings; the book cost five shillings. After a trial of the new remedies, they wrote to the doctor, stating that there was no improvement. This brought down a rejoinder, in which the doctor demanded six guineas for his fee, at the same time stating that he was only making half his usual charge. This was what Luther calls a "belly-go-fister."
The poor people reasoned with him, but a writ was threatened, and the like. As they were dependent on their children for their daily bread, they offered to pay through a bank one pound per week. This follower of the Lamb and the apostles, however, would have his "pound of flesh" all at once, and he got it. The "doctor," in a list of terms at the end of his book, says that he attends the poor of London gratuitously; this in a great measure tempted my poor townsfolk. I enclose you the letter which the " doctor" forwarded to his patients, threatening them with writs.

Keighley, June 16 th, 1815 . Your obedient servant,

Jomn Milligan.

\section{NEWS OF THE WEEK, REMARKS, AND CRITICISMS.}

Causes of Labour and of the Duration of Gestation.-The menstrnal period in the human female comes on, it is well-known, at regular intervals of twenty-eight days. Conception occurs after the menstrual period, while the ovum is in the Graafian vesicle, the Fallopian tubes, or the uterus. The duration of pregnancy is forty weeks or 280 days-that is to say, exactly to menstrual periods, $28+10=280$.

The restrual period of the rabbit comes on every ten days. Conception occurs during the æstrum. Gestation in the rabbit extends over three periods. Kindling takes place at the thirtieth day after impregnation, $10+3=30$.

The æstrual period of the mare comes on every fourteen days. Conception occurs during the æstrum. Gestation in the horse extends over twenty-four periods. The mare foals at the 355 th day after impregnation, $24+14=356$

The æstrual period of the cow comes on every twenty-two days. Conception occurs during the æestrum. Gestation extends over thirteen æstrual periods. Calving takes place on the 285 th day, $22+13=286$.

In all these instances, it will be seen that the period of gestation is some multiple of an æstrual or menstrual period. These calculations are made from animals taken promiscuously. The presumption is therefore in favour of the establishment, as an universal law extending to all mammalia, that the period of natural gestation is invariably composed of some multiple of the æstrual or menstrual periods. Besides the establishment of this law, these data point to the actual cause of the coming on of labour at its particular time in the mammalia. If in the human female abortions occur, it is known that they very often occur at the time for the recurrence of the menstrual periods, and it is also known that in dysmenorrhœal or menorrhagic patients abortion is very prone to occur at the periods immediately following the conception. The first contractions of the uterus in labour in perfectly natural cases may be excited in a reflex form by the irritability of the ovaria, at the tenth period from conception.

The data for the calculations are taken from Professor Naegele, Mr. Girdwood, Tessier, and Lord Spencer.-From a Correspondent.

Last Report from the National Vaccine Establishment to Sir James Graham, Bart., \&c.-Sir: After the recent communication of the results of an inquiry, instituted, at your desire, into the prevalence of small-pox, and the protective influence of vaccination, we have only to repeat in this our annual report the unabated confidence with which we continue to regard vaccination.

Amongst the encouraging circumstances which have presented themselves to our notice during the last year, is that of the Government district vaccinators at Port Louis, Mauritius, having vaccinated many thousand children, and been enabled to keep up a constant supply of pure lymph.

During the last year, the National Vaccine Institution has supplied one hundred and seventy-five thousand three hundred and sixty-two charges of lymph, and met the demands contained in the letters of five thousand eight hundred and forty-five correspondents, the majority of whom required lymph, not only for their individual service, but for that of extensive distribution thus multiplying, to an indefinite extent, the benefits disseminated by this national institution.

John Ayrton Paris, M.D., B. C. Brodie, \&c.

(From a Correspondent.) - Mr. Power, dentist, Stephen's-Green, Dublin, has found it desirable, in the course of his professional duties, after the extraction of a tooth, that the gum should not be closed, as the natural spreading of the adjoining teeth on either side of the tooth which has been extracted is thereby prevented. When the jaw has received injury, in the course of a rude operation, it is judicious to bring the parts into contact. 